\title{
APPLICATION OF A MULTI-CRITERIA ANALYSIS APPROACH FOR DECISION-MAKING IN THE ENERGY SECTOR: THE CASE OF CONCENTRATING SOLAR POWER IN SOUTH AFRICA
}

\author{
E.K. Broughton ${ }^{\mathrm{a}}$, A.C. Brent ${ }^{\mathrm{a}, \mathrm{b}^{*}}$ and L. Haywood \\ ${ }^{a}$ Graduate School of Technology Management, University of Pretoria, \\ South Africa \\ E-mail: alan.brent@up.ac.za \\ ${ }^{b}$ Centre for Renewable and Sustainable Energy Studies, School of Public Leadership, \\ Stellenbosch University, South Africa \\ E-mail: acb@sun.ac.za \\ 'Natural Resources and the Environment, Council for Scientific and Industrial Research, \\ South Africa \\ E-mail: lhaywood@csir.co.za
}

\begin{abstract}
The current decision-making processes that are involved in Environmental Impact Assessments in the energy sector of South Africa suffer from, amongst others, the lack of coherence and the integration of the opinions of decision-makers ${ }^{1}$ in the assessments. The processes also do not adequately evaluate the trade-offs between social, economic, political and environmental issues that are identified for proposed projects, and alternatives if applicable. This paper demonstrates the application of a multi-criteria analysis approach to address these challenges. The application is based on a proposed concentrating solar power plant, for which the Environmental Impact Assessment process has been completed.
\end{abstract}

Keywords: Multi-criteria decision analysis, energy sector, decision-making, South Africa.

\section{INTRODUCTION}

Environmental Impact Assessments (EIAs) investigate trade-offs that lead to conflicts in decision-making $[1,2]$. The more diverse the impacts in terms of social, economic, political and environmental issues, the more difficult it is to compare them due to the different nature of these impacts, and the measurements used in their assessments [3]. Thus, tools are required that: allow an efficient integration of the diverse issues that affect decisions, whereby the information is conveyed to decision-makers ${ }^{1}$; and make the decision-making process more transparent.

The purpose of this paper is to demonstrate the application of one of these tools, namely the Multi Criteria Analysis (MCA) approach. This tool has been extensively used throughout the world to assist with making a decision when there is a need for the identification of trade-offs and conflicting objectives are involved. The MCA approach brings a number of advantages to the decision-making process such as transparency, facilitation of communication between stakeholders, and the provision of a structured approach to decision-making [4]. Examples where it has been applied include the assessment, and

1 Decision-makers refer to the designated, responsible authorities, at Provincial or National level, that by law - the National Environmental Management Act - are required to provide Environmental Authorisation, or not, of proposed developments. The Record of Decision (RoD), if positive, typically contains mitigation measures or other aspects that, according to the decision-makers, must be monitored after commissioning in order to ensure that the development adheres to the conditions of the EIA RoD. In the case of approval being required at the National level, then the decision-maker is housed in the Department of Environmental Affairs in Pretoria; if at Provincial level, a similar department will appoint a decision-maker. 
prioritisation, of the sustainability of agricultural projects in rural areas [5], and the establishment of health care waste management systems that minimise infection risks in developing countries [6]. Also for ElAs, the MCA approach has been applied for over two decades [7]. In the South African context, however, it has been applied to a limited degree, and especially so for EIAs in the energy sector. Thus, the paper demonstrates the application of the MCA approach for a proposed concentrating solar power (CSP) project in the Northern Cape Province of South Africa, for which the EIA process had been conducted [8]. The paper concludes with the feedback that had been received from the decisionmakers themselves.

\subsection{Framework utilised for the MCA approach}

The process that was followed was adopted from Dodgson et al. [9] and included eight steps (see Fig. 1). The first three steps were modified slightly and re-named to be more appropriate to the EIA process.

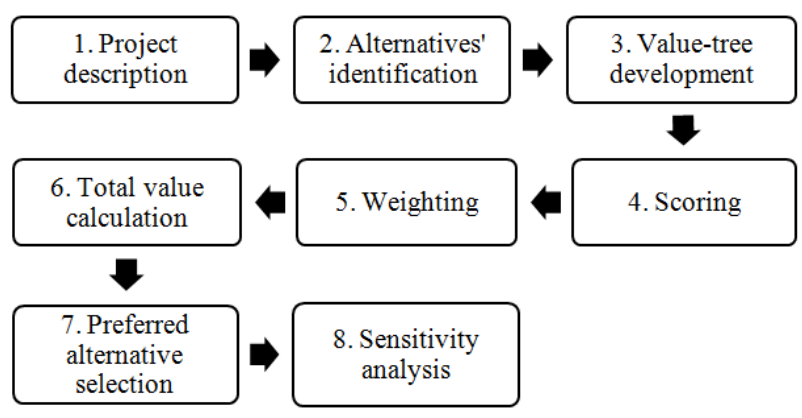

Figure 1. Framework utilised for the MCA approach Source: adopted from Dodgson et al. [9]

\section{Project description}

A complete description of the proposed CSP project can be found elsewhere [8]. The EIA for the project included the following specialist studies:

- Impacts on surface and groundwater;

- Impacts on ecology and flora;

- Impacts on terrestrial fauna;

- Impacts on soils and agricultural potential;

- $\quad$ Avifaunal impacts;

- $\quad$ Heritage resource impacts;

- $\quad$ Noise impacts;

- Impacts on tourism;

- $\quad$ Social impact assessment and land use; and

- Visual impacts.

\section{Alternatives}

The proposed development considered three site alternatives, but the preferred option was chosen during the scoping phase [8]. The specialist studies, therefore, were conducted for the plant and its associated infrastructure for one site only, and comparing this option with a "no-go" option.

\section{Value tree development}

The development of a value tree, or a hierarchy of impacts, followed a "bottom-up" approach. The logic outlined by Wilson et al. [10] was followed by, first, extracting the impacts from the specialist studies, and then grouping the impacts into categories, which in 
turn were aggregated into three dimensions, namely economic, environmental, and social. A list of sixty-two impacts was established, which were then grouped into thirteen categories in the three dimensions. The grouping followed a cluster analysis technique and resulted in the development of a value tree for the CSP project (see Fig. 2).

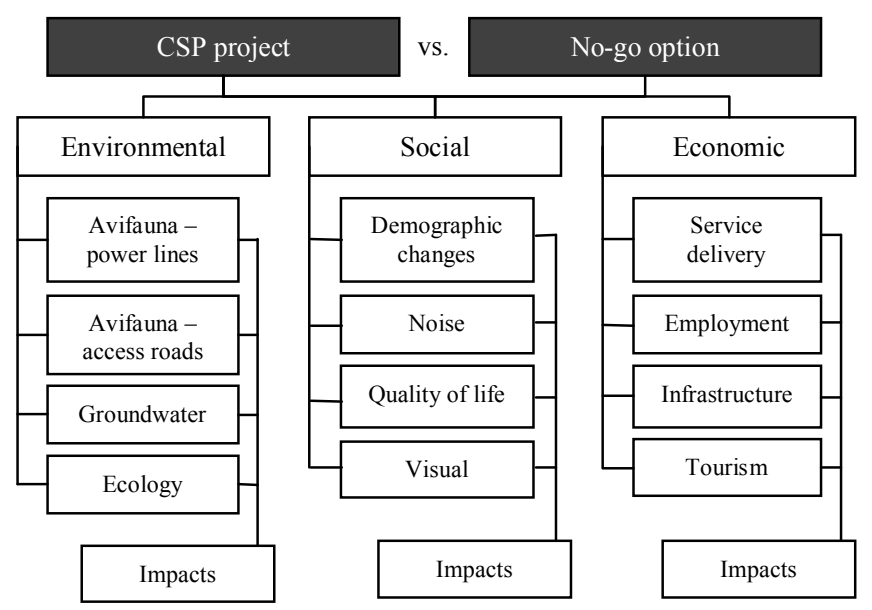

Figure 2. CSP value tree

Source: Broughton [11]

Performance matrix development (scoring)

A performance matrix was developed for the case study for two situations: before and after mitigation measures have been introduced. Each performance matrix included a list of impacts, unit of measurement, type of impacts (positive or negative), and score for the impact. The information was sourced either from ranking tables developed by specialists, or from the body of their respective reports.

Since the rating of impacts made use of a qualitative range, they were first converted into quantitative form following the assumptions indicated in Table 1. Using the product of scores assigned to the significance and the degree of confidence, the scores for the performance matrix were determined. In situations where no indication of risk or the degree of confidence was given, it was assumed that it received the highest score, namely Definite. Where no indication of the significance of the impact after mitigation was given in the rating tables, it was assumed that it would receive the same significance rating as in the case before mitigation.

Table 1. Conversion of qualitative rankings into a quantitative form

\begin{tabular}{|ll|}
\hline Significance: & Degree of confidence (probability): \\
\hline - Neutral - 0 & - Unsure/ unlikely - 15 \\
- Very low - 5 & - Possible/improbable -25 \\
- Low - 15 & - Probable -50 \\
- Moderate/medium - 50 & - Highly probable - 80 \\
- Moderate/Medium to high - 80 & \\
- High - 100 & \\
- Very high - 150 & \\
Source: Broughton [11] &
\end{tabular}




\section{Weighting}

Weights were assigned to every level and impact in the value tree. In order to ensure the validity of the results obtained the pairwise comparison and direct weighting techniques for weighting were used [9]. This paper only reports on the pairwise comparison technique; details on the pairwise and direct weighting techniques are documented by Broughton [11]. The set of discreet choices that was used in the pairwise comparisons was adopted from Triantaphyllou et al. [12]. Overall, the following approach was followed:

- Weights for impacts were determined by specialists.

- Weights for categories, or the middle level of the value tree, were determined by an independent EIA specialist.

- Weights for dimensions, namely the highest level of the value tree, were assigned by the decision-makers, in particular employees of the national Department of Environmental Affairs who agreed to participate.

Total value calculation

The calculation of the Total Value Index (TVI) followed the weighted sum method (WSM) [9].

Ranking and preferred alternative selection

After the TVI was calculated, its net effect was compared against the "no-go" option, which was assumed to have a zero value. A positive TVI, or net benefit, of the project indicated that the positive impacts created by the project would not only balance out the negative effects, but would surpass them. This meant that the project would improve the current situation from a holistic perspective. A negative TVI, however, meant that the project would ultimately result in a worse situation than the current status quo. The calculation of TVIs was also done for the situations before and after mitigation. This assisted with the understanding of the importance of mitigation measures and the extent by which the negative and positive impacts could be improved.

\section{Sensitivity analysis}

The sensitivity analysis involved the identification of the most critical impact, category or dimension that would affect the decision. The identification of the most important criteria was done through a one-dimensional approach. Thereby, every weight was increased by $5 \%$ while keeping the remainder of the weights at the same level of the hierarchy constant. After the weight was changed, the percentage variation in the TVI was determined. Those criteria for which a $5 \%$ change in weight would lead to the largest percentage variation of the TVI were considered as the most important criteria of the value tree. However, only those weights that change the sign of the project's net effect (TVI) were considered to be critical.

\section{OUTCOMES AND DISCUSSION OF THE APPLICATION OF THE MCA APPROACH}

\subsection{Results using weights derived from the pairwise comparison technique}

The detailed analysis and outcomes are provided elsewhere [11]. Table 2 summarises the weights that were assigned to the impacts, categories and dimensions. The table indicates that the most important, from the perspectives of decision-makers, was the economic dimension, followed by social and then environmental. 
Table 2: CSP weights assigned for impacts, categories and dimensions

\begin{tabular}{|c|c|c|c|c|c|}
\hline Impact/category/dimension & $\begin{array}{l}\text { Pairwise } \\
\text { comparison }\end{array}$ & $\begin{array}{c}\text { Direct } \\
\text { weighting }\end{array}$ & Impact/category/dimension & $\begin{array}{l}\text { Pairwise } \\
\text { comparison }\end{array}$ & $\begin{array}{c}\text { Direct } \\
\text { weighting }\end{array}$ \\
\hline $\begin{array}{l}\text { ENVIRONMENTAL } \\
\text { DIMENSION }\end{array}$ & $21.8 \%$ & $17.2 \%$ & SOCIAL DIMENSION & $30.2 \%$ & $24.5 \%$ \\
\hline $\begin{array}{l}\text { Groundwater category } \\
\text { Migration of contaminants }\end{array}$ & $39.4 \%$ & $30 \%$ & Noise category & $20.7 \%$ & $30 \%$ \\
\hline $\begin{array}{l}\text { from Orange River water used } \\
\text { in CSP }\end{array}$ & $4.6 \%$ & $2 \%$ & Noise - construction phase & $83.3 \%$ & $60 \%$ \\
\hline $\begin{array}{l}\text { Migration of hydrocarbon fuel } \\
\text { spillage at the plant }\end{array}$ & $63.8 \%$ & $75 \%$ & Noise - operational phase & $16.7 \%$ & $40 \%$ \\
\hline $\begin{array}{l}\text { Leaching of herbicides used } \\
\text { in ground sterilis. beneath the } \\
\text { mirrors }\end{array}$ & $20.4 \%$ & $2 \%$ & Quality of life category & $53.6 \%$ & $35 \%$ \\
\hline $\begin{array}{l}\text { Leaching of } \mathrm{Na} / \mathrm{K}-\mathrm{NO} 3 \text { salts } \\
\text { (used as coolant) }\end{array}$ & $11.2 \%$ & $21 \%$ & $\begin{array}{l}\text { Impact on daily living and } \\
\text { movement patterns - } \\
\text { construction }\end{array}$ & - & $15 \%$ \\
\hline Avifaunal category - plant & $5.7 \%$ & $10 \%$ & $\begin{array}{l}\text { Impact on daily living and } \\
\text { movement patterns - operation }\end{array}$ & - & $15 \%$ \\
\hline Collision with heliostats & $21.7 \%$ & $5 \%$ & Disruption of social networks & & \\
\hline $\begin{array}{l}\text { Collision with central receiver } \\
\text { tower }\end{array}$ & $4.6 \%$ & $10 \%$ & $\begin{array}{l}\text { and alteration of family } \\
\text { structures - construction }\end{array}$ & - & $12 \%$ \\
\hline $\begin{array}{l}\text { Roosting on central receiver } \\
\text { tower }\end{array}$ & $4.0 \%$ & $5 \%$ & $\begin{array}{l}\text { Social impact derived from } \\
\text { industrial diversification - } \\
\text { construction }\end{array}$ & - & $8 \%$ \\
\hline $\begin{array}{l}\text { Burning in vicinity of central } \\
\text { receiver tower }\end{array}$ & $5.3 \%$ & $10 \%$ & $\begin{array}{l}\text { Social impact derived from } \\
\text { industrial diversification - } \\
\text { operation }\end{array}$ & - & $8 \%$ \\
\hline Burning in focal points & $36.9 \%$ & $30 \%$ & Social impact derived from the & & \\
\hline Habitat loss & $13.5 \%$ & $20 \%$ & $\begin{array}{l}\text { environmental and economic } \\
\text { benefits of solar power }\end{array}$ & - & $20 \%$ \\
\hline Disturbance & $9.8 \%$ & $15 \%$ & $\begin{array}{l}\text { Air and dust pollution - } \\
\text { construction }\end{array}$ & - & $3 \%$ \\
\hline Nesting & $4.2 \%$ & $5 \%$ & Light intrusion - construction & - & $3 \%$ \\
\hline $\begin{array}{l}\text { Avifaunal category - power } \\
\text { lines }\end{array}$ & $20.7 \%$ & $25 \%$ & Noise intrusion - construction & - & $5 \%$ \\
\hline Collision of birds & $76.6 \%$ & $80 \%$ & $\begin{array}{l}\text { Air and dust pollution - } \\
\text { operation }\end{array}$ & - & $3 \%$ \\
\hline Habitat destruction & $15.8 \%$ & $10 \%$ & Light intrusion - operation & - & $3 \%$ \\
\hline Disturbance & $7.6 \%$ & $10 \%$ & Noise intrusion - operation & - & $5 \%$ \\
\hline $\begin{array}{l}\text { Avifaunal category - access } \\
\text { road }\end{array}$ & $5.7 \%$ & $10 \%$ & $\begin{array}{l}\text { Demographic changes } \\
\text { category } \\
\text { Introduction of people }\end{array}$ & $13.8 \%$ & $15 \%$ \\
\hline Disturbance & $50.0 \%$ & $60 \%$ & $\begin{array}{l}\text { dissimilar in demographic } \\
\text { profile - construction } \\
\text { Introduction of people }\end{array}$ & $30.4 \%$ & $35 \%$ \\
\hline Habitat destruction & $50.0 \%$ & $40 \%$ & $\begin{array}{l}\text { dissimilar in demographic } \\
\text { profile - operation }\end{array}$ & $7.8 \%$ & $15 \%$ \\
\hline Ecology category & $28.5 \%$ & $25 \%$ & $\begin{array}{l}\text { Inflow of temporary workers - } \\
\text { construction }\end{array}$ & $15.4 \%$ & $30 \%$ \\
\hline Impact on vegetation & $50 \%$ & $50 \%$ & $\begin{array}{l}\text { Introduction of new social } \\
\text { classes }\end{array}$ & $46.3 \%$ & $20 \%$ \\
\hline Impact on fauna & $50 \%$ & $50 \%$ & Visual category & $11.9 \%$ & $20 \%$ \\
\hline ECONOMIC DIMENSION & $48.0 \%$ & $54.8 \%$ & Major tourism routes & - & $20 \%$ \\
\hline Tourism category & $13.7 \%$ & $20 \%$ & Residential areas: Upington & - & $20 \%$ \\
\hline $\begin{array}{l}\text { Change in tourism and leisure } \\
\text { opportunities - construction }\end{array}$ & $20 \%$ & $40 \%$ & $\begin{array}{l}\text { Residential areas: Louisvale, } \\
\text { Louisvel Road, Kanon Eiland }\end{array}$ & - & $9 \%$ \\
\hline
\end{tabular}




\begin{tabular}{|c|c|c|c|c|c|}
\hline Impact/category/dimension & $\begin{array}{l}\text { Pairwise } \\
\text { comparison }\end{array}$ & $\begin{array}{c}\text { Direct } \\
\text { weighting }\end{array}$ & Impact/category/dimension & $\begin{array}{l}\text { Pairwise } \\
\text { comparison }\end{array}$ & $\begin{array}{c}\text { Direct } \\
\text { weighting }\end{array}$ \\
\hline $\begin{array}{l}\text { Change in tourism and leisure } \\
\text { opportunities - operation }\end{array}$ & $80 \%$ & $60 \%$ & $\begin{array}{l}\text { Residential areas: Oranje } \\
\text { Valley, Ses Brugge, Klippunt }\end{array}$ & - & $9 \%$ \\
\hline Employment category & $31.3 \%$ & $30 \%$ & Protected areas: Spitkop NR & - & $13 \%$ \\
\hline $\begin{array}{l}\text { Employment equity and } \\
\text { occupation opportunities - } \\
\text { construction }\end{array}$ & $27.5 \%$ & $35 \%$ & $\begin{array}{l}\text { Protected areas: Augrabiesd } \\
\text { Falls NP }\end{array}$ & - & $2 \%$ \\
\hline $\begin{array}{l}\text { Creation of employment } \\
\text { opportunities - construction }\end{array}$ & $9.2 \%$ & $40 \%$ & Impact on Orange River & - & $8 \%$ \\
\hline $\begin{array}{l}\text { Employment equity and } \\
\text { occupation opportunities - } \\
\text { operation }\end{array}$ & $47.5 \%$ & $10 \%$ & $\begin{array}{l}\text { Ancillary infrastructure: salt } \\
\text { tanks }\end{array}$ & - & $2 \%$ \\
\hline $\begin{array}{l}\text { Creation of employment } \\
\text { opportunities - operation }\end{array}$ & $15.8 \%$ & $15 \%$ & $\begin{array}{l}\text { Ancillary infrastructure: } \\
\text { auxiliary house }\end{array}$ & - & $2 \%$ \\
\hline Service delivery category & $23.8 \%$ & $25 \%$ & $\begin{array}{l}\text { Ancillary infrastructure: } \\
\text { transmission line }\end{array}$ & - & $2 \%$ \\
\hline $\begin{array}{l}\text { Impact on municipal services } \\
\text { requirements - construction }\end{array}$ & $83.3 \%$ & $60 \%$ & $\begin{array}{l}\text { Ancillary infrastructure: pipe } \\
\text { line }\end{array}$ & - & $2 \%$ \\
\hline $\begin{array}{l}\text { Impact on municipal services } \\
\text { requirements - operation }\end{array}$ & $16.7 \%$ & $40 \%$ & Lighting: glare- floodlights & - & $5 \%$ \\
\hline Infrastructure category & $31.3 \%$ & $25 \%$ & $\begin{array}{l}\text { Lighting: glare-aircraft warning } \\
\text { lights }\end{array}$ & - & $5 \%$ \\
\hline $\begin{array}{l}\text { Change in community } \\
\text { infrastructure - construction }\end{array}$ & $16.7 \%$ & $60 \%$ & Lighting: spill light & - & $3 \%$ \\
\hline $\begin{array}{l}\text { Change in community } \\
\text { infrastructure - operation }\end{array}$ & $83.3 \%$ & $40 \%$ & Lighting: sky glow & - & $3 \%$ \\
\hline
\end{tabular}

Source: Broughton [11]

Table 3 provides the results of the TVI calculation for the cases before and after mitigation using the weights derived through the pairwise comparison technique (see Table 2). The figures presented in the weight-adjusted column show that, first, the categories' scores multiplied by their respective weights, and second, dimensions' scores calculated as the sum of category scores multiplied by the respective dimension's weight. The table also shows the maximum and minimum amount that could be scored by each dimension and category, given the assigned weights, which were used to calculate the normalised values of the scores.

Table 3 indicates that all environmental and social impacts for the CSP project are negative and that the maximum score that they can obtain, taking into account the weights, is zero. At the same time, the economic dimension has both positive and negative impacts. The total maximum score, given the respective weights for categories and dimensions, can be a positive 21.6.

Overall a negative TVI value is calculated for the case before mitigation. This score means that when compared to the "no-go" option, the CSP project is not the preferred option as it would have an overall negative effect. The comparison of scores, calculated before and after mitigation, suggest that the mitigation measures proposed by certain specialists will significantly reduce the overall negative impact of the project.

A question is raised with respect to the employment category scoring a lower positive value in the case after mitigation than the value obtained in the case before mitigation. Since the mitigation of positive impacts is aimed at increasing their overall probability of occurrence, the positive score for the case after mitigation should either remain the same as for the case before mitigation or increase. Since the results show that it was reduced, it could be argued that the specialist who assigned new sets of probability and significance values for 
Table 3: Results using weights derived through pairwise comparison

\begin{tabular}{|c|c|c|c|c|c|c|}
\hline \multirow[t]{2}{*}{ Impact } & \multicolumn{2}{|c|}{ Actual values } & \multicolumn{2}{|c|}{ Weight-adjusted } & \multicolumn{2}{|c|}{ Range } \\
\hline & $\begin{array}{c}\text { Before } \\
\text { mitigations }\end{array}$ & $\begin{array}{c}\text { After } \\
\text { mitigations }\end{array}$ & $\begin{array}{c}\text { Before } \\
\text { mitigations }\end{array}$ & $\begin{array}{c}\text { After } \\
\text { mitigations }\end{array}$ & Min & $\operatorname{Max}$ \\
\hline Environmental & - & - & -5.0 & -4.1 & -21.8 & 0 \\
\hline Groundwater & -24.2 & -24.2 & -9.5 & -9.5 & -39.4 & 0 \\
\hline Ecology & -15.0 & 0.0 & -4.3 & 0.0 & -28.5 & 0 \\
\hline Avifauna - CSP plant & -51.3 & -51.3 & -2.9 & -2.9 & -5.7 & 0 \\
\hline Avifauna - power lines & -22.7 & -22.7 & -4.7 & -4.7 & -20.7 & 0 \\
\hline Avifauna - access roads & -30.0 & -30.0 & -1.7 & -1.7 & -5.7 & 0 \\
\hline Subtotal & $\overline{-}$ & - & -23.1 & -18.8 & - & - \\
\hline Social & - & - & -4.0 & -0.4 & -30.2 & 0 \\
\hline Visual & -45.9 & -45.7 & -5.5 & -5.5 & -11.9 & 0 \\
\hline Noise & -6.9 & -6.9 & -1.4 & -1.4 & -20.7 & 0 \\
\hline Quality of life & -7.9 & 12.2 & -4.2 & 6.5 & -53.6 & 0 \\
\hline Demographic changes & -15.5 & -7.1 & -2.1 & -1.0 & -13.8 & 0 \\
\hline Subtotal & - & - & -13.3 & -1.3 & - & - \\
\hline Economic & - & - & 2.2 & 3.5 & -26.4 & 21.6 \\
\hline Employment & 54.6 & 23.3 & 17.1 & 7.3 & 0.0 & 31.3 \\
\hline Tourism & 7.5 & 23.0 & 1.0 & 3.2 & 0.0 & 13.7 \\
\hline Infrastructure & -10.4 & -3.3 & -3.3 & -1.0 & -31.3 & 0.0 \\
\hline Service delivery & -42.9 & -8.8 & -10.2 & -2.1 & -23.8 & 0.0 \\
\hline Subtotal & - & - & 4.6 & 7.3 & - & - \\
\hline TVI & - & - & -6.83 & -0.99 & -78.4 & 21.6 \\
\hline
\end{tabular}

Source: Broughton [11]

the employment impacts made an error. If this was the case, it could also be expected that the value of the economic dimension after mitigation would have been greater. The result is that the TVI after mitigation could be reduced to neutral or even become positive, illustrating that the positive impacts associated with the CSP project have the ability to counterbalance the negative impacts derived from it.

The final scores calculated for each dimension and the TVI can be normalised to indicate the extent to which the impacts under the respective dimensions trace behind the most beneficial situation, or the maximum score that could be obtained for the respective dimension. This assessment could be useful in exploring the areas that have the largest potential to be mitigated to reduce the negative score of the project or to improve its benefits, as well as the extent by which the proposed mitigation measures are extenuating the impacts. As illustrated in Fig. 3, the mitigation measures proposed for the social dimension's impacts are expected to have the greatest success and reduce the negative impacts by a greater amount than in the case of other dimensions. At the same time, it appears that the greatest potential for mitigation and improvement of the performance of the CSP project lies in the economic dimension. 


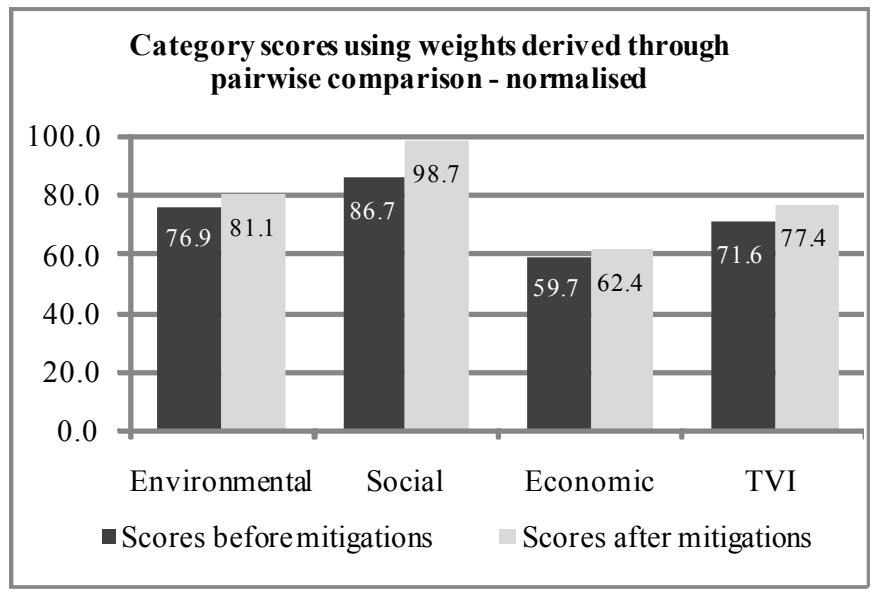

Figure 3: Normalised scores using weights pairwise comparison weights Source: Broughton [11]

\subsection{Sensitivity analysis results}

Table 4 presents the results of the sensitivity analysis. They show the net TVI calculated as a result of increasing the weight by $5 \%$ of the respective category or dimension.

Table 4: Sensitivity analysis pairwise comparison weights

\begin{tabular}{|c|c|c|c|c|c|c|}
\hline \multirow{2}{*}{ Impact } & \multicolumn{3}{|c|}{ Before mitigation } & \multicolumn{3}{|c|}{ After mitigations } \\
\hline & New TVI & $\begin{array}{c}\text { TVI \% } \\
\text { change }\end{array}$ & Rank & New TVI & $\begin{array}{l}\text { TVI \% } \\
\text { change }\end{array}$ & Rank \\
\hline Environmental & -7.99 & $17 \%$ & 2 & -1.93 & $96 \%$ & 1 \\
\hline Groundwater & -7.09 & $4 \%$ & 8 & -1.25 & $27 \%$ & 8 \\
\hline Ecology & -6.99 & $2 \%$ & 14 & -0.99 & $0 \%$ & 16 \\
\hline Avifauna - CSP plant & -7.39 & $8 \%$ & 6 & -1.54 & $57 \%$ & 4 \\
\hline Avifauna - power lines & -7.08 & $4 \%$ & 10 & -1.23 & $25 \%$ & 9 \\
\hline Avifauna - access roads & -7.16 & $5 \%$ & 7 & -1.31 & $33 \%$ & 7 \\
\hline Social & -7.49 & $10 \%$ & 5 & -1.05 & $7 \%$ & 15 \\
\hline Visual & -7.52 & $10 \%$ & 4 & -1.68 & $70 \%$ & 2 \\
\hline Noise & -6.93 & $2 \%$ & 16 & -1.09 & $11 \%$ & 13 \\
\hline Quality of life & -6.95 & $2 \%$ & 15 & -0.80 & $-19 \%$ & 11 \\
\hline Demographic changes & -7.06 & $3 \%$ & 11 & -1.09 & $11 \%$ & 12 \\
\hline Economic & -6.60 & $-3 \%$ & 12 & -0.62 & $-37 \%$ & 6 \\
\hline Employment & -5.52 & $-19 \%$ & 1 & -0.43 & $-57 \%$ & 3 \\
\hline Tourism & -6.65 & $-3 \%$ & 13 & -0.43 & $-56 \%$ & 5 \\
\hline Infrastructure & -7.08 & $4 \%$ & 9 & -1.07 & $8 \%$ & 14 \\
\hline Service delivery & -7.86 & $15 \%$ & 3 & -1.20 & $21 \%$ & 10 \\
\hline
\end{tabular}

Source: Broughton [11] 
The table shows that the sensitivity of the model differed for the cases before and after mitigation. In the situation when mitigation had not yet been introduced, the results of the model based on the pairwise comparison weights were most sensitive to the changes of weights of categories such as employment and service delivery, as well as to the changes in weights of the environmental dimension.

For the case after mitigation, the results were sensitive to the changes of most of the categories, in particular to the change in the weight for the environmental dimension, which showed that a $5 \%$ increase of its weight resulted in the TVI for the project nearly doubling (in a negative way). Categories that were most sensitive to changes in weights with the change results in $50 \%$ to $70 \%$ change in the score one way or the other - included visual, employment, tourism, and avifauna.

It was also clear that among the top five most sensitive categories and dimensions three appear in both cases - before and after mitigation. These were the environmental dimension, the visual category, and the employment category. Interestingly, the employment and visual categories were considered to be the greatest contributors to the scores of the respective dimension, while the environmental dimension had the greatest contribution to the TVI, despite it being given the lowest weights amongst the dimensions.

\section{CONCLUSIONS}

The paper reveals that the MCA approach can be applied effectively to projects undergoing an Environmental Impact Assessment process in the energy sector. It shows that the approach can be used to determine the trade-offs between environmental, social, and economic dimensions taking into account the opinions of specialists, the Environmental Assessment Practitioners involved in the specific project, and, importantly, decisionmakers. The MCA approach also has the ability to clearly show the benefits of introduced mitigation measures, and particularly the extent by which negative impacts associated with the project could be reduced and positive impacts improved.

The decision-makers that were interviewed during the study supported the use of the MCA approach. They agreed that the method provides for a consistent approach to the evaluation of projects, but questioned the transparency of the approach if interested and affected parties are not involved right from the start. Also, an over-reliance on numerical representation of values can obscure the necessary subjectivity in the decision-making process, which needs to be made transparent. To this end, they emphasised that the utilised framework could not be the only solution to improving the process of decisionmaking as other factors also affect this process. Further, they indicated that the usefulness of the MCA approach depended on the range of ratings that are used to assess the impacts, as the limited range (used here) could never provide for a clear indication of differences between alternatives. Herein lies the potential to improve the MCA method in the EIA process context.

\section{REFERENCES}

1 Stahl, C.H., Cimorelli, A.J. and Chow, A.H., A new approach to environmental decision analysis: Multi Criteria Integrated Resource Assessment (MIRA), Bulletin of Science, Technology and Society, 2002, 22(6), 443-459.

2 Glasson, J., Environmental Impact Assessment - Impact on Decisions. In: Petts, J., ed., Handbook of EIA Volume 1: Process, Methods and Potential, Blackwell Science, Oxford, 1999, 121-144.

3 Gibson, R., Sustainability assessment: Basic components of a practical approach, Impact Assessment and Project Appraisal, 2006, 24(3), 170-182. 
4 Belton, V. and Stewart, T.J., Multiple criteria decision analysis: An integrated approach, Kluwer Academic Press, London, 2002.

5 Mulder, J. and Brent, A.C., Selection of sustainable agriculture projects in South Africa: Case studies in the LandCare programme, Journal of Sustainable Agriculture, 2006, 28(2), 55-84.

6 Brent, A.C., Rogers, D.E.C., Ramabitsa-Siimane, T.S.M. and Rohwer, M.B., Application of the Analytical Hierarchy Process to establish Health Care Waste Management systems that minimise infection risks in developing countries, European Journal of Operational Research, 2007, 181, 403-424.

7 Bisset, R., Development in ElA methods. In: Wathern, P., ed., Environmental impact assessment: Theory and practice, Routledge, 1988, 47-61.

8 Bohlweki Environmental, Environmental Impact Assessment Process - Northern Cape Area (CSP) plant and associated infrastructure, Eskom, 2006, http://www.eskom.co.za/c/article/402/northern-cape-area-csp-plant-andassociated-infr/, accessed 13 December, 2011.

9 Dodgson, J., Spackman, M., Pearman, A. and Philipps, L. DTLR Multi Criteria Analysis Manual, National Economic Research Associates (NERA), 1999, http://iatools.jrc.ec.europa.eu/public/IQTool/MCA/DTLR_MCA_manual.pdf, accessed 13 December, 2011.

10 Wilson, D.C., Whiteman, A. and Tormin, A, The strategic planning guide - Annex 4: Multi-criteria analysis, International Bank for Reconstruction and Development, World Bank, 2001.

11 Broughton, E.K., A framework for coherent decision-making in environmental impact assessments in the energy sector of South Africa, Masters Dissertation, Graduate School of Technology Management, University of Pretoria, 2011, http://upetd.up.ac.za/thesis/available/etd-03292011-201613/, accessed 13 December, 2011.

12 Triantaphyllou, E., Mann Jr., B., Kovalerchuk, L. and Knapp, G., Determining the most important criteria in maintenance decision-making, Journal of Quantity in Maintenance Engineering, 1997, 3(1), 16-28. 